\section{Snus gir økt dødsrisiko}

I tidligere oversiktsstudier om risikoen for kardiovaskulær sykdom hos brukere av røykfri tobakk, f.eks. snus og skrå, har man konkludert med at det ikke er grunnlag for å si at det er noen sammenheng. Franske forskere har nå gjort en metaanalyse for å se om brukere av røykfri tobakk i Sverige og USA har økt risiko for kardiovaskulær sykdom (BMJ 2009; 339: b3060).

Studiene fra både Sverige og USA viste at det var økt dødsrisiko pga. hjerteinfarkt og slag ved bruk av røykfri tobakk. Data for dose-respons-forhold var begrenset, men viste ingen sterk sammenheng mellom frekvens eller varighet og dødsrisiko pga. disse sykdommene. På grunn av større heterogenitet mellom studier av ikke-fatal kardiovaskulær sykdom, som alle var utført i Sverige, ble en liknende sammenheng som for fatal sykdom ikke påvist.

\section{Pneumoni ved inhalasjonssteroider?}

Det har vært diskutert om inhalasjonssteroider fører til økt risiko for lungebetennelse hos pasienter med kronisk obstruktiv lungesykdom (kols).

I en metaanalyse med 7000 pasienter, der 4000 brukte budesonidinhalasjon og 3000 kontrollpersoner placebo- eller formoterolinhalasjon, fant man ingen $ø \mathrm{kt}$ risiko for pneumoni etter ett års behandling hos dem som fikk steroidinhalasjon (Lancet 2009; 374: 712-9). De eneste variablene som var assosiert med signifikant økt risiko for lungebetennelse var økende alder og minkende prosent av forventet $\mathrm{FEV}_{1}$.

\section{Raltegravir mot hiv-1-infeksjon}

Raltegravir i kombinasjonbehandling er effektivt og godt tolerert hos pasienter med multiresistent hiv-1-infeksjon (Lancet 2009; 374: 796-806).

I en multisenterstudie undersøkte man effekten av raltegravir som førstegangsbehandling. 550 pasienter ble randomisert til enten raltegravir eller efavirenz, begge i kombinasjon med tenofovir eller emtricitabin. Det primære endepunkt var reduksjon til $<50$ virus-RNA/ml etter 48 uker.

Det var ikke signifikant forskjell i måloppnåelse, henholdsvis $86 \%$ og $82 \%$. Derimot var det signifikant færre bivirkninger i raltegravirgruppen (44\%) enn i efavirenzgruppen (77\%). Raltegravir er altså et godt alternativ til efavirenz, også for dem som ikke har forsøkt annen behandling først.

\title{
Tynnere hjernebark ved schizofreni
}

\author{
Pasienter med schizofreni har tyn- \\ nere hjernebark enn normalt. Kan \\ dette være bindeleddet mellom arve- \\ lig disposisjon og sykdom?
}

Utvidede sideventrikler og redusert kortikal tykkelse i hjernen er et av de best studerte makroanatomiske funn ved schizofreni. Sykdommen er i stor grad genetisk betinget. Hvis kortikal tykkelse er arvelig og hjernebarken er tynnere også hos personer med genetisk betinget forhøyet risiko for schizofreni, kan kortikal tykkelse være en såkalt intermediær fenotype - dvs. en genetisk mediert patologisk-anatomisk endring som virker som et bindeledd mellom genetisk påvirkning og sykdomsutvikling.

I en studie med 115 pasienter med schizofreni var flere områder av hjernebarken hos disse, særlig i frontallappen og temporalt, signifikant tynnere enn hos 196 friske kontrollpersoner (1). 192 uaffiserte søsken til pasientene hadde tynnere hjernebark enn kontrollgruppen. De statistiske analysene viste at hjernebarktykkelse var signifikant arvelig.

\section{Lavkarbohydratdiett gunstig ved type 2-diabetes}

\section{Et kosthold med lite karbohydrater} og mye olivenolje, såkalt middelhavskost, ser ut til å være bedre for overvektige med type 2 -diabetes enn en fettfattig diett.

Vektreduksjon er en viktig del av diabetesbehandlingen hos overvektige. I en italiensk studie ble 215 overvektige med nyoppdaget type 2-diabetes randomisert i to grupper (1). Den ene gruppen ble bedt om å holde seg til en diett der $<50 \%$ av det daglige kaloriinntaket skrev seg fra karbohydrater og $>30 \%$ fra olivenolje, den andre gruppen skulle følge en diett $\operatorname{der}<30 \%$ av det daglige kaloriinntaket kom fra fett. Etter fire år hadde $44 \%$ av pasientene i lavkarbohydratgruppen behov for antihyperglykemisk behandling, mot $70 \%$ i gruppen som hadde levd på fettfattig diett $(\mathrm{p}<0,001)$. Gruppen med middelhavsdiett gikk mer ned i vekt, hadde bedre glukosekontroll og fikk større reduksjon i risikofaktorer for koronar hjertesykdom.

- Denne studien var ikke blindet for behandlende leger, og kostinntaket ble registrert av pasientene selv. Dette gjør funnene
- Hvis den høye arveligheten av schizofreni skulle kunne forklares ut fra direkte genetisk påvirkning på hjernebarkens tykkelse, ville man forventet større forskjell mellom kontrollpersonene og pasientenes søsken, sier overlege Ingrid Agartz ved Psykiatrisk avdeling, Diakonhjemmet Sykehus.

Resultater fra andre studier, bl.a. en norsk studie med svenske pasienter, tyder imidlertid på at verken sykdomsvarighet eller antipsykotisk behandling påvirker tykkelsen på hjernebarken. - Vi arbeider nå med studier av spesifikke genvarianter og andre faktorer som vi vet øker risikoen for schizofreni, og ser på sammenhengen mellom disse og volumet av ulike hjernestrukturer, sier Agartz.

\section{Ragnhild Ørstavik}

ragnhild.orstavik@fhi.no Tidsskriftet

\section{Litteratur \\ 1. Goldman AL, Pezawas L, Mattay VS et al. Wide- spread reductions of cortical thickness in schizo- phrenia and spectrum disorders and evidence of heritability. Arch Gen Psychiatry 2009; 66: 467-77.}

noe usikre, påpeker seksjonsoverlege Tore Julsrud Berg ved Endokrinologisk avdeling, Oslo universitetssykehus, Aker.

Det nye med studien er at effekten vedvarer så lenge som fire år. Studien viser også at man kan senke $\mathrm{HbA}_{1 \mathrm{c}}$-nivået like mye med kostholdsendringer som med nyere medikamenter med uavklart bivirkningsprofil.

- Studien tyder på at lavkarbohydratdiett kan være positivt for overvektige med type 2-diabetes, istedenfor fettfattig kost eller medikamentell behandling. Mange pasienter har brukt denne typen diett i flere år, og nå begynner den vitenskapelige dokumentasjonen å komme, sier Berg.

\section{Petter Gjersvik \\ petter.gjersvik@legeforeningen.no \\ Tidsskriftet \\ Litteratur \\ 1. Esposito K, Maiorino MI, Ciotola M et al. Effects of a Mediterranean-style diet on the need for anti- hyperglycemic drug therapy in patients with newly diagnosed type 2 diabetes. Ann Intern Med 2009; 151: $306-14$.}

